\title{
Anthós
}

Volume 10 | Issue 1

Article 9

$6-21-2021$

\section{Before Beachie Creek}

\author{
Raine Welterlen \\ Portland State University
}

Follow this and additional works at: https://pdxscholar.library.pdx.edu/anthos

Part of the Biodiversity Commons, Illustration Commons, and the Painting Commons Let us know how access to this document benefits you.

Recommended Citation

Welterlen, Raine (2021) "Before Beachie Creek," Anthós: Vol. 10: Iss. 1, Article 9.

https://doi.org/10.15760/anthos.2021.10.1.9

This open access Article is distributed under the terms of the Creative Commons Attribution-NonCommercialShareAlike 4.0 International License (CC BY-NC-SA 4.0). All documents in PDXScholar should meet accessibility standards. If we can make this document more accessible to you, contact our team. 


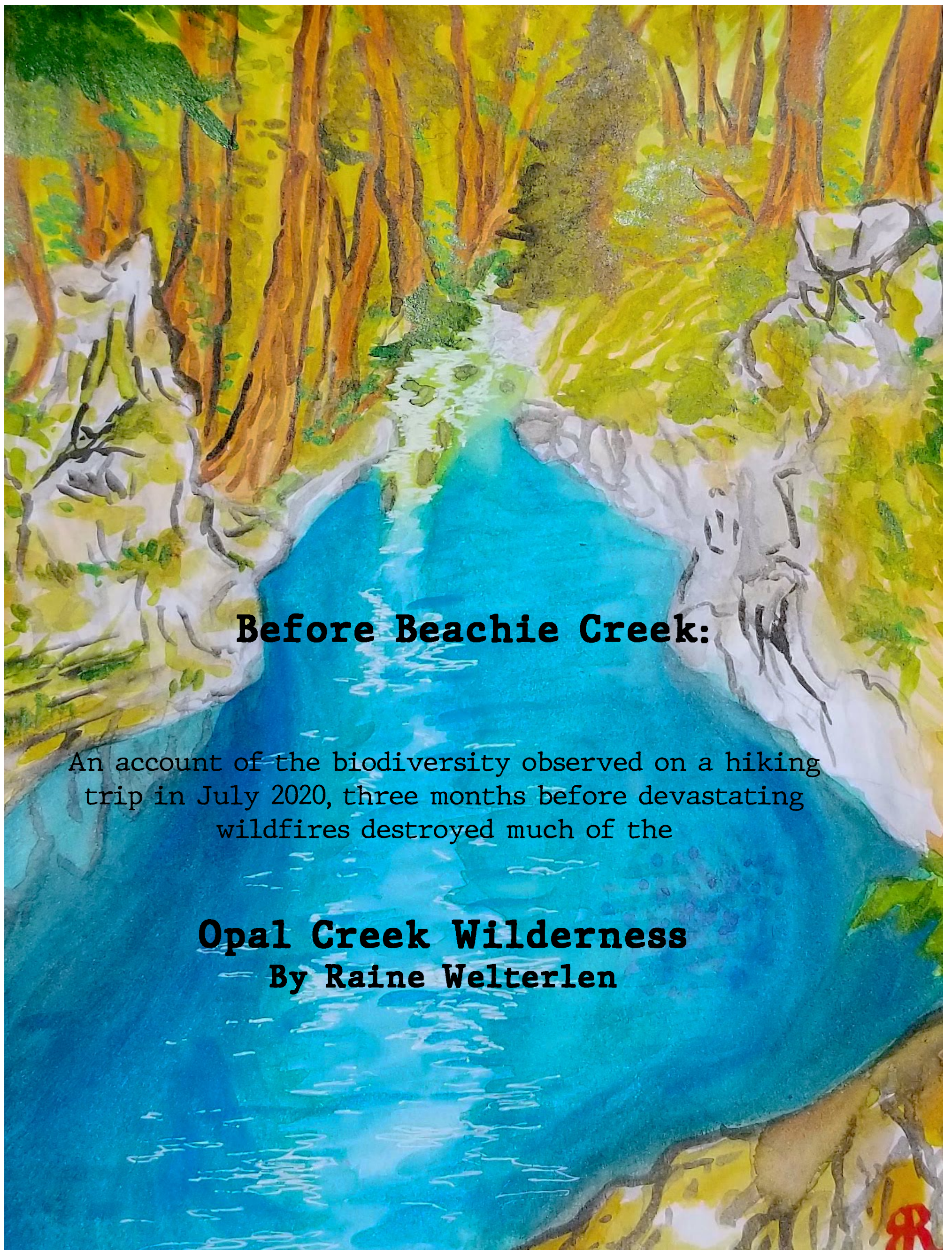




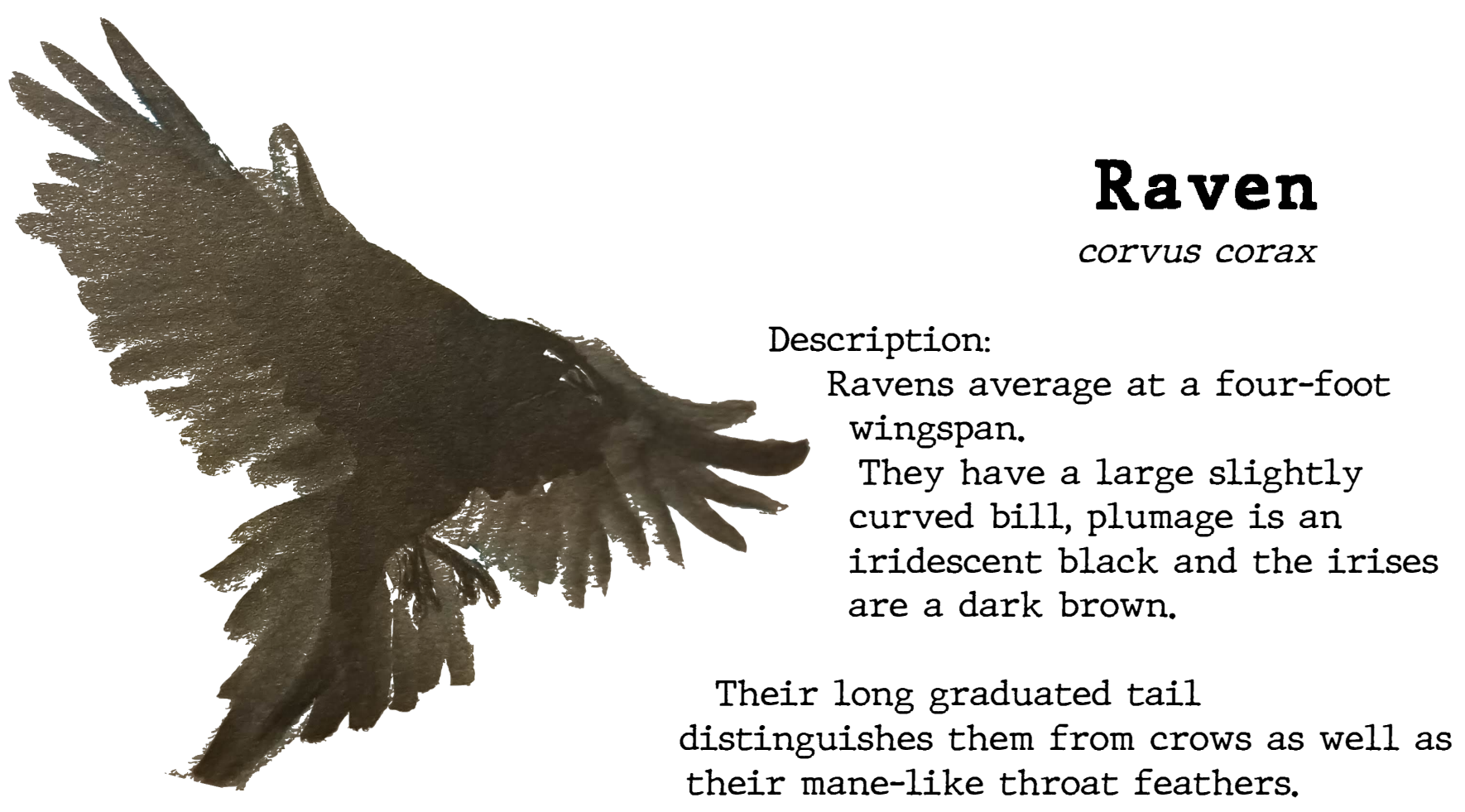

Live in most northern parts of the world preferring wooded areas with large expanses of open land.

Omnivorous, consuming anything from carrion, insects, cereal grains, berries, to food waste.

Ravens have a upwards of thirty different types of vocalizations including their deep sonorous croak. Quarrelsome but devoted to their families. Young birds may travel in flocks but later mate for life with each pair defending their own territory. Arial acrobatics, demonstrations of intelligence, and ability to provide food are key behaviors in courting.

Ravens are one of four animals known to have displacement. 


\section{Wormwood}

\section{Artemisia absinthium}

Wormwood is an herbaceous perennial plant with fibrous roots native to temperate Eurasia and Northern Africa but has been naturalized in Canada and the Northern United States.

2 to 4 foot straight grooved branched with silvery-green stems.

Leaves are spirally arranged and have a greenish grey coloring above and white below. Leaves can grow to almost 10" long being bipinnate or tripinnate on its long stalks. Younger leaves are usually between 2 and 4" long and with shorter stalks. Covered in silky silverywhite hairs and have oil-bearing glands

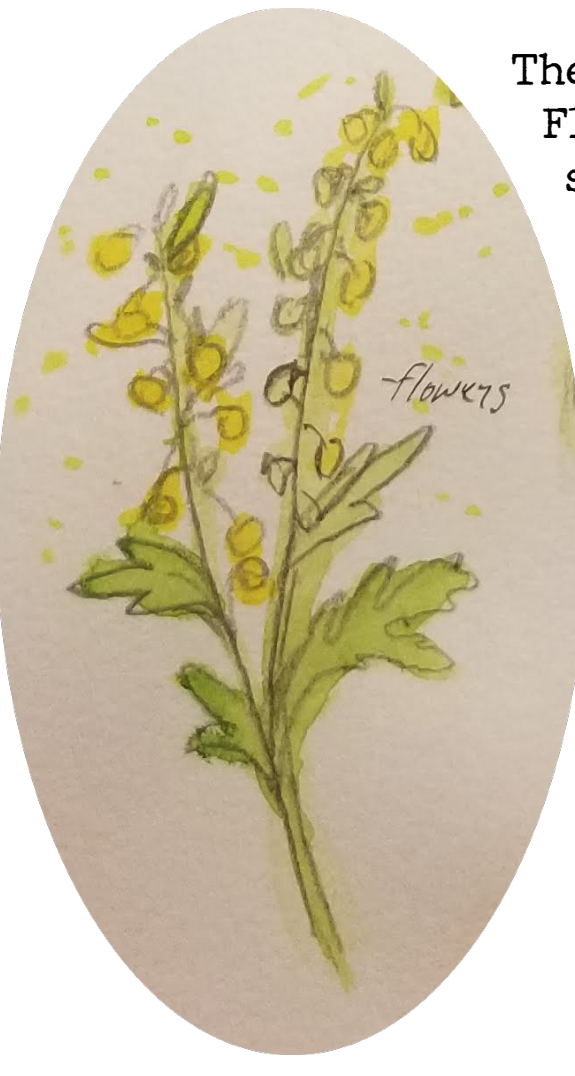

They bloom from early summer to early autumn.

Flowers are pale yellow, tubular and clustered in spherical bent-down heads. They are anemophilous their pollen spread by the wind.

Grows on uncultivated arid ground and rocky slopes at the edge of footpaths and fields.

Has a very bitter flavor that is used to flavor absinthe and other alcoholic beverages, though high consumption can cause convulsions.

Used in medicine to help with indigestion, and other problems with the digestive tract. 


\section{Banana Slug}

Ariolimax Columbianus

This species of Banana Slug are often bright yellow, which is where they get their name, but they can also appear greenish, brown, tan or white.

Looking for their smooth mantle, foot fringe, and a prominent pneumostome on its right side, which is the entrance to their single lung, can help with identification.

Will grow up to 9.8 " long in its 7-year lifespan. Its two eyestalks, which are really no more than tentacles, are retractable and can be regrown if bitten off.

Typically active at night or during cool wet days. Will hibernate during the dry season, known as aestivation.

Can only move 6.5 " a minute

Slugs have both the male and female reproductive organs.

Slugs are detritivores or decomposers and process leaves, animal droppings, moss and dead plant material and recycle it into soil hummus

Often eaten by raccoons, garter snakes, ducks, geese and salamanders. Predators will roll the slugs in soil to bind the mucus as its mucus can numb their tongue.

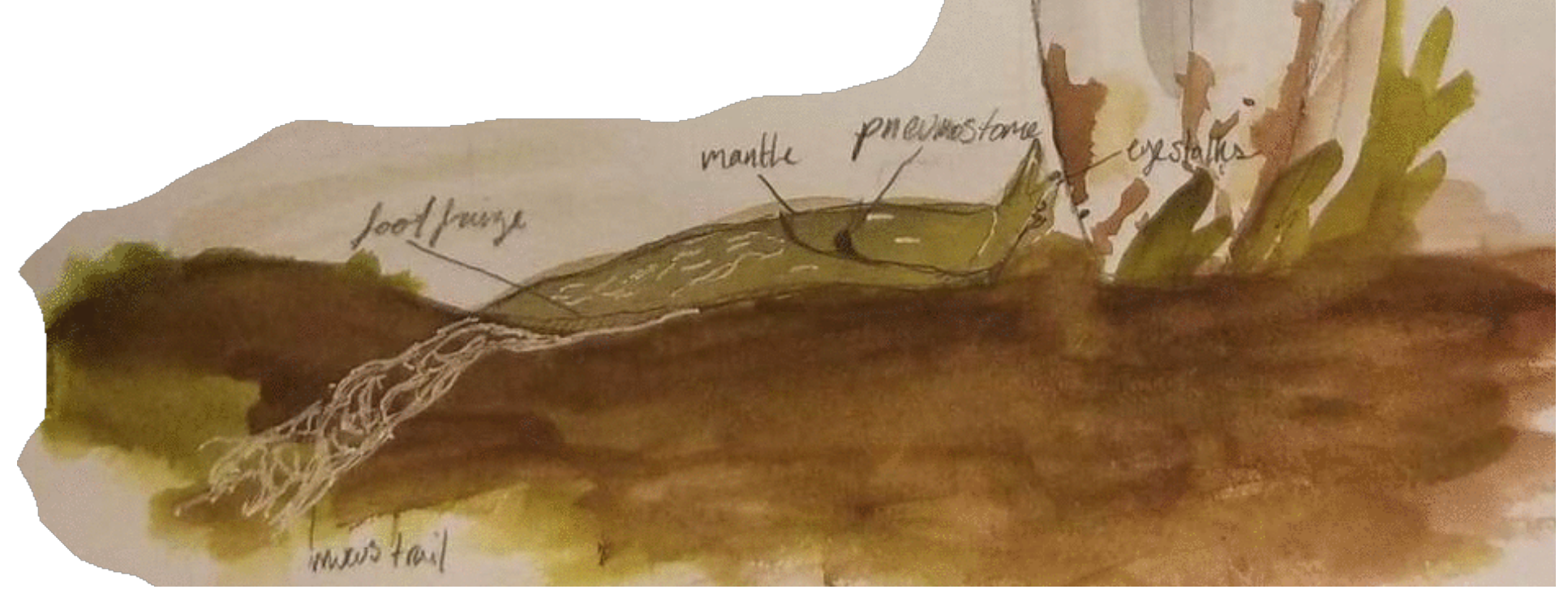




\section{Western Red Cedar}

thuja plicata

Evergreen coniferous tree in the cypress family, it is not a true cedar of the genus Cedrus

Often found alongside the Douglas fir and Western Hemlock.

Can grow in forested swamps and under dense shade. Some specimens have been $210-230 \mathrm{ft}$. tall with a 10$23 \mathrm{ft}$. diameter trunk.

Oldest verified specimen of the western red cedar was 1460 years old

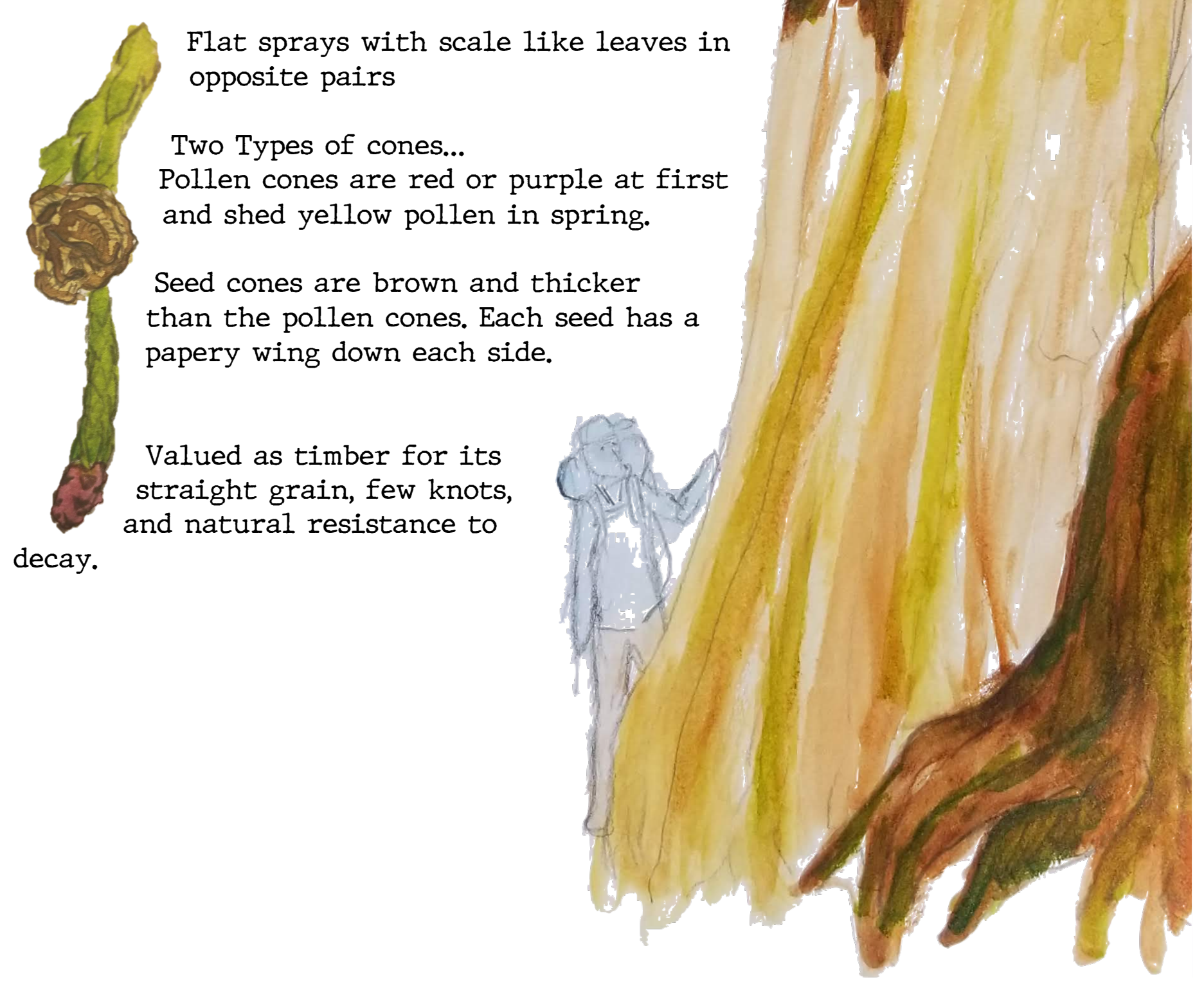




\section{Aquatic Pacific Giant Salamander}

Dicamptodon tenebrosus

Endemic to Pacific Northwest

Can grow up to a foot long Larvae are aquatic with external gills

They have long laterally compressed tails

Can mature into adulthood in the aquatic form of the larvae or develop into the terrestrial form, which is brown with black marbling.

Larvae form similar to Cope's Giant Salamander, which rarely develops into the terrestrial adult form.

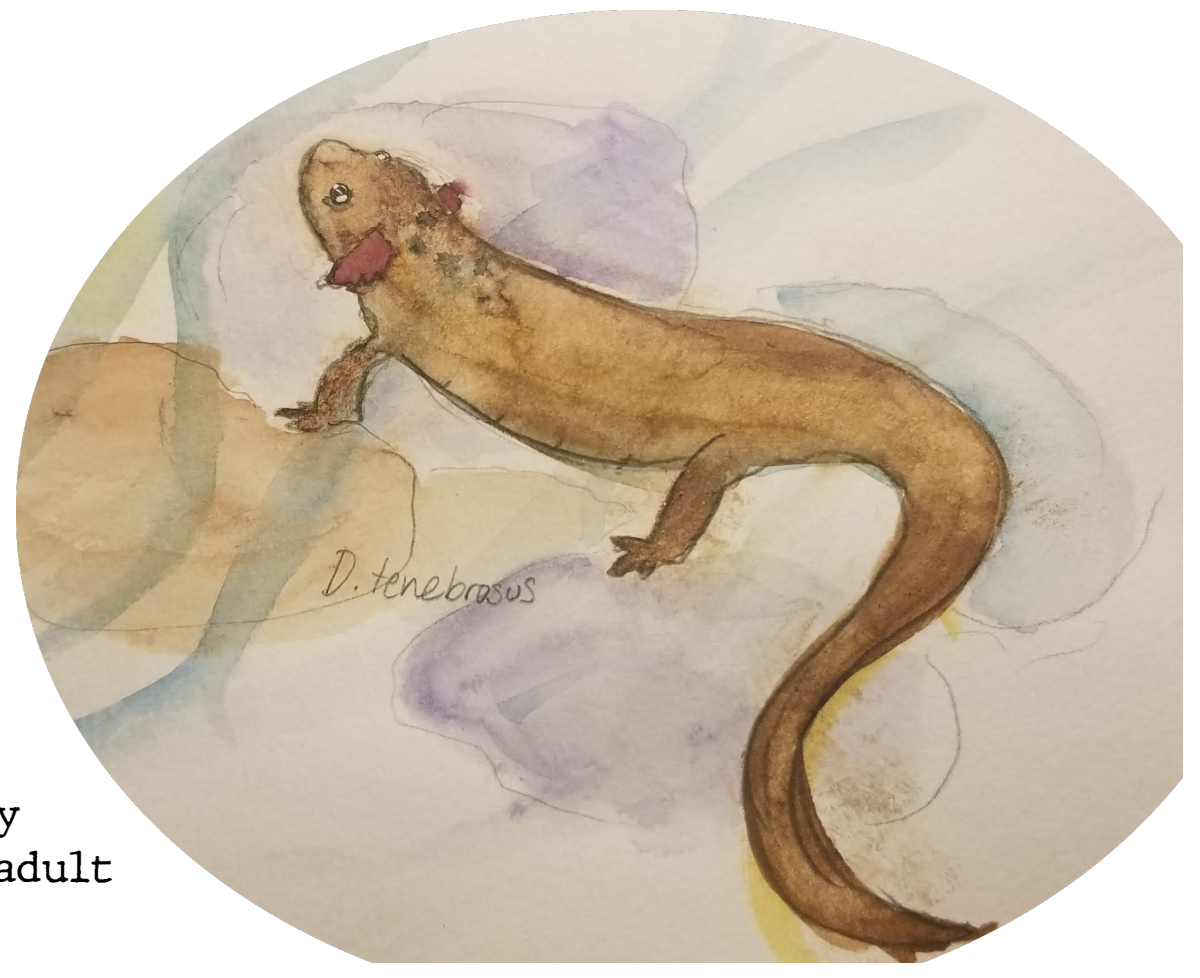

You can tell them apart by the pacific salamander's wide protruding eyes, costal grooves, thick arms and darker coloring...

...where Cope's has a more golden coloring, no visible costal grooves, and only grows to be 8 " long.

Cope's salamanders are also limited to The Clatsop and Mount Hood Forests, and can't migrate past the Lower White River Wilderness.

Prefer Cold mountain streams and ponds next to forests.

They hide under rocks during the day and come out at night.

When startled, Pacific Giant

Salamanders can respond with a croaky-cry similar to a barking dog. 


\title{
History of Opal Creek
}

\author{
1850 -1869 Gold found in Opal Creek \\ 1848 - Oregon becomes the $33^{\text {rd }}$ State in the Union \\ 1929-1934 - Jawbone flats developed
}

1964 - Oregon Wilderness Act does not include Opal Wilderness

1969 - George Atiyeh becomes caretaker of Jawbone flats

1972 - George Atiyah forms Shiny Rocks Mining Co. to block forest service plans

1976 - "The Hidden Wilderness: A Hikers Guide" Published

1981 - Boundary markers placed for Opal Creek Timber Sale

1981- Two different appeals made against the sale, both denied.

1984 - Oregon Wilderness Act does not include Opal Wilderness

1988 - George Atiyeh builds public trail into Opal Creek

1989 - "Easter Massacre" where protesters against the North Roaring Devil

Timber Sale were arrested after chaining themselves to trees

1989 - Friends of Opal Creek established to promote protection of Opal Creek

1989 - "Ancient Forests: Rage Over Trees" is Broadcast

1993 - Time magazine article "The Showdown at opal creek: The Battle for

America's Last Wilderness" by David Seideman is published

1994 - Opal Creek Forest Preserve Act \& Northwest Forest Plan

1996 - Opal Creek Wilderness and Scenic Recreation Area Becomes a State Park

2005 - Friends of Opal Creek Becomes Opal Creek Ancient Forest Center

George Atiyeh Died in the Beachie Creek Fire in 2020 


\section{Sources}

"Artemisia Absinthium." Plant Finder, Missouri Botanical Garden, www.missouribotanicalgarden.org/PlantFinder/PlantFinderDetails.aspx?ke mpercode $=$ a938.

Berg, Rachel. "Corvus Corax (Common Raven)." Animal Diversity Web, University of Michigan Museum of Zoology , 1999, animaldiversity.org/site/accounts/information/Corvus_corax.html.

Bury, R. Bruce, et al. "Differentiation of Isolated Populations of Two Giant Salamander Species ( Dicamptodon) East of the Oregon Cascade Mountian Crest, USA." Herpetological Conservation and Biology, vol. 12, 30 Apr. 2017, pp. 171-181.

Minore, Don. "Thuja Plicata ." Thuja Plicata, St. Paul Field Office, srs.fs.usda.gov/pubs/misc/ag_654/volume_1/thuja/plicata.htm.

"Pacific Giant Salamander." Burke Museum, www.burkemuseum.org/collectionsand-research/biology/herpetology/amphibians-reptileswashington/pacific-giant.

Thomas, Kristen. "Ariolimax Columbianus." Animal Diversity Web, University of Michigan Museum of Zoology , 2000,

animaldiversity.org/site/accounts/information/Ariolimax_columbianus.ht $\mathrm{ml}$.

Urness, Zach. "Timeline of Events: The Fight for Opal Creek." Statesman Journal, USA Today, 24 Sept. 2016, wWw.statesmanjournal.com/story/news/2016/09/24/timeline-events-fightopal-creek/90757086/.

Vlach, Joshua. Slugs and Snail in Oregon: 2016A Guide to Common Land Mollusks and Their Relatives. Oregon Department of Agriculture Guides . 